\title{
RAF Family Gene Mutation
}

National Cancer Institute

\section{Source}

National Cancer Institute. RAF Family Gene Mutation. NCI Thesaurus. Code C136425.

A change in the nucleotide sequence in a RAF family gene. 